\title{
A Historical Investigation into Persian Modal Auxiliaries
}

\author{
Jalal Rahimian, Hossein Najari, Shole Hesarpuladi \\ Shiraz University, Shiraz, Iran \\ Email: jrahimian74@gmail.com
}

Received 5 July 2015; accepted 24 August 2015; published 27 August 2015

Copyright (C) 2015 by authors and Scientific Research Publishing Inc.

This work is licensed under the Creative Commons Attribution International License (CC BY). http://creativecommons.org/licenses/by/4.0/

(c) (i) Open Access

\begin{abstract}
Modal verbs are typically used in expressing conditional situations and events. This research aims at investigating into the history of modal verbs in Persian from Old to Modern period. Based on the written data related to Old Persian, this language lacks any modal verb. In this period of Persian, conditional events and situations are expressed by other means, including certain verb moods and adverbs. In uncertain periods of Middle Persian four main verbs related to Old Persian had been implemented in new capacities, known as modal verbs, to express modalized events and situations. In Modern Persian, only two of the four Middle Persian modal verbs, namely, tavănestan and băyestan, plus a new modal verb called šodan are used in expressing different kinds and degrees of modality. However, it was revealed that the range of meanings expressed by Modern Persian modals is not as diverse as those used in Middle Persian.
\end{abstract}

\section{Keywords}

Old Persian, Middle Persian, Modern Persian, Modality, Modal Verbs

\section{Introduction}

An event or a situation can be expressed either conditionally or unconditionally.

Consider the following pairs, for instance:

1) She writes the letter.

2) She must write the letter.

The event expressed in 1) is actualized independent of any condition. However, in 2) we are talking about some event that is necessary to happen. Technically, 1) is called unmodalized, while 2) is referred to as modalized. In different languages there are different means of expressing modalized sentences. In a number of languages (especially African and Indian languages), modalized events and situations are expressed by certain verb 
moods. In some languages different adverbs are used in expressing modality. Yet, in a vast number of languages, there are a limited number of verbs which are specifically used in expressing modality. Such verbs are called modal verbs. Persian is among languages which make use of all of the above three means in expressing modality. This paper aims at looking into the history of modal verbs in Persian.

As Huddleston and Pullum (2002) maintain, in different languages of the world there are concepts such as tense, aspect, mood, voice and modality which would be expressed by means other than lexical verbs. In fact, in a vast majority of languages there are a limited number of verbs, known as auxiliaries, which are used to express the above concepts. Such verbs were, in the remote past, among lexical verbs whose roles as main verbs necessarily changed to auxiliary roles. A number of scholars, including Huddleston (1984), divide auxiliary verbs into central auxiliaries and modal auxiliaries. The focus of this paper will be on the history of modal auxiliaries in Persian.

\section{Old and Middle Persian}

As far as Old Persian concerns, no concept as modal auxiliary is found among sources regarding this period of Persian language. In fact, there is no reliable evidence showing at what period modal verbs appeared in Middle Persian. Based on Kent (1953: 169), the verb upa-ay "to approach, to reach" is among Old Persian lexical verbs. This verb seems to be the source of Middle Persian modal verb $a b \bar{a} y$ - "must" which is referred to by Mackenzie (1971: 2). This verb appears in a new capacity, namely, modal function, in Middle Persian. Abāy-ist-an is composed of the present stem $a b \bar{a} y$-, the past tense marker ist, and the infinitive marker -an. Rastorgueva [translated by Shădăn (2000)], holds that abāyistan "must" is among the most common modal verbs of Middle Persian. Among different Middle Persian texts, one can find examples with the inflected forms $a b \bar{a} y$-: abāyennd, abāyēd, abāyist. Consider the following examples:

3) ud pad kirbagkard-an tuxšăgabāyēd bud-an [Mirfaxraee (2011: chap. 62, par. 16)].

And to good-deeddid-INFV active must was-INFV Andone must be active in performing good deed.

The above would be used in a context where the speaker expects and wishes a long period of reign for the addressee. It also implies that the people are in need of his rule.

4) ...ka-šsāanāg tar abāyistbūd [Mirfaxraee (2011: chap. 31, par. 9a)].

...that-s/he learned-COMPV must was. INFV

...the time when it was necessary to be more learned

The above represents a very typical example of the uses of the modal abāyistan where the speaker holds that a certain situation was necessary to actualize.

Horn (1893: 774) presents xšay- "to rule, to reign” among Old Persian lexical verbs. Kellens (1995: 17) gives $x \check{s} \bar{a}$ - "to be able to" in the Avesta. Formally, this root changed into present stem $\check{s} \bar{a} y$ - and the infinitives ša $\bar{a}$ idan and šâyistan "to deserve, to be able to" in Persian. According to different Persian examples, one can say that it possessed a new capacity to express some kinds of modality. As a modal auxiliary, it was used to show that an event or situation has the capacity to be actualized. $\check{s} \bar{a} y$-ist-an is composed of the root, šây-, the past tense marker, -ist- and the infinitive marker, -an. According to a number of scholars, including Rastorgueva [translated by Shădăn [(2000)] and Khanlari (1987), šâyistan "to deserve, to be able to" is among the most common modal verbs of Middle Persian. According to Rastorgueva, Middle Persian šāyistan appears in three plural forms: $\check{s} \bar{a} y \bar{e} m$ (1PL), šāyéd (2PL) and šāyend (3PL). However, the vast majority of his examples are in third person singular form. According to the examples, one can say that šâyistan have a range of meanings:

5) ...è don menêd kū ān weh-iz šâyèd büd kū man. [Mirfaxraee (2011: chap. 62, par. 19)].

...so thought. 3SG that it better-too maybe was. 3SG than I

... He thought that he might be better than he was

6) ...ka Ahreman parwastag kardan ne šăyēd. [Rashed Mohassel (2006: chap. 1, par. 12)].

...If Satan encompassed did-INFV not can

...That one cannot put Satan in Jail

7) ...pad èn se čiš šāyeed büdan. [Rashed Mohassel (2006: chap. 1, par. 20)].

...to this three things can was-INFV

...It can be possible with these three things

8) ...dō pad èk ne šâyed bawēd. [Mirfaxraee (2011: chap. 58, par. 85)].

...two to one not can is. 3SG

...Two does not fit one 
9) may šāyēd. [Mirfaxraee (2011: chap. 58, par. 18)].

wine is. worth

Wine is worth

As far as form is concerned, Brandenstein and Mayrhofer (1964: 143) list šiyav- "to go, to move", among Old Persian lexical verbs which changed into šaw- "to go, to move" in Middle Persian. No sign of modal use of šodan is seen in Middle Persian. Apparently, in an uncertain stage of modem Persian it was used in a new capacity as a modal auxiliary to express concepts such as "ability", "possibility" or "permission".

Middle Persian modal auxiliary tuwănistan "to be able to" has its roots in the Old Persian noun tauman"power, force" though some scholars, including (Mayrhofer I: 490), hold that it is derived from the root tav- "to be powerful”. According to Mansuri and Hasanzadeh (2008) tuvānist is among Middle Persian modal verbs. In Middle Persian it was used to express concepts such as "ability and possibility". It was typically accompanied by the infinitive form of the main verb of the sentence:

10) ...kešid-an nē tuwānist [Amuzgar (2003: chap. 49, par. 2)]. ...pulled-INFV not could ...They could not pull [it].

This modal sometimes preceded the main verb of the sentence:

11) ...to nē tuwān grift-an [Farahvashi (1975: chap. 2, par. 17)].

....you not can caught-INFV

....Nobody can catch you.

According to Mackenzi (1971: 74) the verb root saz- is among Middle Persian verbs, meaning "to deserve, to be worthy”. According to Horn (1893: 738) it is derived from the Old Iranian language non-past stem sača-related to the root sak-, meaning "to be able to". Based on Khanlari (1987), sazidan "to suit, to deserve" is one of the most common modal verbs in Middle Persian. Abolghasemi (2008) holds that the above verbs are used in expressing concepts such as "necessity, obligation, probability and possibility" in Middle Persian. He adds that sazidan was used only in third person singular form.

12) $u$-š èč èwēnag abāz ayārist-an nēsazèd. and-he no method again dared-INFV not can It is impossible that he dares [attacking] again

13) ...pad rāhī xrad be abēgumānīhā sazēed dānist-an. [Oryan (1992: par. 2)]. ...to path LINK wisdom with objectivity can knew-INFV ....It suits one to know by wisdom that.

14) ān $\bar{\imath}$ sazēd menēd. [Mirfaxraee (2011: chap. 62, par. 23)]. It that can thinking It is worth thinking about

15) Pad-iš a-nìrmad-ē sazèd büd. [Amuzgar \& Tafazzoli (2007: chap. 21, par. 2)]. to-it harmful can was. 3SG Thus, it can be harmful

\section{Modern Persian}

According to the vast majority of Iranian scholars, including Shariat (1985), Givi and Anvari (1991), Meshkatodini (2000), Rahimian (1995 \& 2012), and Rahimian and Amuzadeh (2013), Modern Persian contains three modal verbs, namely, băyad, šodan and tavānestan. Băyad is a, modal with a fairly vast range of uses, roughly comparable to English must, should, ought to, have to and even will, depending on the context. in fact, a substantial part of the meaning of băyad is derived from the context:

16) băyad xāne rā be-foruš-am must house COMP NIN-sell. NPS-l SG

I must sell the house

The above would be used in a context where the speaker is considerably in debt and the only way of paying the debt is to sell his/her house. Accordingly, here băyad reflects a high degree of obligation on the part of the speaker. Now, consider the following:

17) băyad xăne-ye bozorgtar-i be-xar-am must house-LINK larger-INDEFNIN-buy. NPS-ISG

I should buy a larger house 
The above would be used in a context where the speaker is not happy with the size of his/her house and would like to have a larger one. However, the problem is not that urgent and s/he is not obliged to change it quickly. In this case, băyad is equivalent to English should.

Interestingly, băyad, as a modal verb, can be used as an equivalent for English will:

18) mehdi băyad tă hălă be tehrăn rasid-eh băš-ad

Mehdi must till now to Tehran reach-PTCPL NIN. be-3SG

Mehdi will have arrived in Tehran by now

The above would be used in a context where the speaker expects Mehdi to have arrived in Tehran at the speech moment.

As Palmer (1990) maintains, one can speak of three kinds and three degrees of modality. As far as kinds of modality are concerned, we hate epistemic, deontic and dynamic modalities. As for degrees of modality, Palmer introduces strong, medium and weak ones. One can see different examples of the above kinds and degrees through băyad in various sentences, depending on the context. When a person draws a logicalconclusion of a situation, s/he deals with epistemic modality:

19) ali băyad bist-săleh băš-ad [epistemic]

Ali must twenty-year-old NIN.be-3SG

Ali must be twenty years old

The above would be used in a context where the speaker asks Ali when he has completed his high school and he answers that he have finished high school two years prior to the speech time. Accordingly, the speaker comes to a logical conclusion that Ali is twenty years old.

Deontic modality is typically used in contexts where the source of power dictates his will to the object of power. Consider the following, for instance:

20) emruz băyad maqăleh ră be man tahvil be-dah-i [doentic]

today must paper COMP to me submission NIN. give. NPs-2SG

Today, you must submit your paper to me

The above would be used in a context where the teacher asks the student to submit his/her paper the day of the speech time otherwise s/he would fail the course. Sentence (20) represents a typical example of deontic modality.

Dynamic modality deals with events and situations created by certain circumstances. Consider the following:

21) in-ruz-ă barăy-e yek mǎšin bǎyad 30 melyun tumăn bepardaz-I [dynamic]

Nowadays for-LINK one automobile must 30 million Tuman NIN. pay. NPS-2SG Nowadays you must pay 30 million Tumans to buy a car

The above would be used in a context where, say, the speaker knows that, based the conditions of car market, buying an average brand new car demands at least 30 million Tumans.

By degree of modality, we mean the extent to which a proposition is possible or probable to be actualized. In English, for instance, must is higher than should in terms of degree of modality. Consider the following examples:

22) i) Your book must be in room 303

ii) Your book should be in room 303

Sentence (22i) would be used in a context where somebody is looking for his/her lost book and the speaker, based on his/her indirect or implicit information regarding the book, says that it must be in room 303 though he did not find the book in that room. By using must, the speaker wants to show that it is the only possible conclusion s/he came to regarding the book and its location. However, if the speaker is not one hundred percent sure regarding the location of the book, s/he would prefer to use should. Accordingly, one can say that must is stronger than should in English.

As far as degree of modality is concerned in Modern Persian, it is a quite context-dependent concept. In other words, it is the context that shows which degree of modality is meant in a sentence. Accordingly, băyad can be used in expressing more than one degree of modality in modem Persian. Huddleston (personal communication) holds that Persian băyad is not capable of expressing strong degree of modality because it does not entail the proposition. One can find different practical Persian examples to support Huddleston's regarding băyad. Unlike English where the speaker cannot follow a sentence like (22i) by a phrase such as "Maybe not”, in Persian băyad and šāyad ham na (which are Persian equivalents for must and maybe not) are normally compatible.

23) ketăb băyad tuy-e otăq-e 303băš-e 
book must in-LINK room 303 NIN. be-3SG

The book must be in room 303

24) šāyad ham na-băs-e maybe either NEG-NIN. be-3SG

Maybe it is not

Sentence (23) would be used in a context where the speaker would like to tell the addressee that the book in question is in a certain room. After a short pause, the same speaker may use the phrase (24) to show that s/he is quite sure about what s/he said. This is why we are of the view that băyad does not entail the proposition and, accordingly, it is not as strong as English must.

25) băyad be xăne be-rav-am [subjunctive]

must to house NIN-go. NPS-1SG

I must go home

26) băyad be xăne raft [short infinitive] must to house went. SHORTINFV One must go home

27) băyad be xăne mi- raft-am [past imperfective] must to house IMPF-went. 1SG I had to go/should have gone home

Besides the above uses, Băyad is also used with subju1ctive perfect structures:

28) payăm băyad farš rā xarid-e băš-ad

Payam must carpet comp bought-PTCPL NIN. be-3SG

Payam must have bought the carpet

The above would be used in a context where the speaker sees Payam carrying a carpet out of the shop and, accordingly, s/he concludes that he has bought the carpet.

In Persian, unlike many languages, băyad takes either of the other two Persian modal verbs:

29) băyad be-se modir ro did must NIN-can manager COMP saw. SHORTINFV

It must be possible to see the manager

30) băyad be-tavan modir ro did

must NIN-can manager comp saw. SHORTINFV

One must be able to see the manager

Both of the above would be used in a context where visiting the manager is something logically possible for people.

Up to last century băyadtook objective person/number endings. Accordingly, forms such as băyad-am, băyadat, băyad-as, băyad-emăn, băyad-etănand băyad-ešănwere quite common:

31) ne-mi-dăn-am če băyad-am kard

NEG-IMPF-know. NPS-ISG what must-ISGdid. INFV

I don't know what I must do

The above would be used in a context where the speaker is quite disappointed with his/her present condition and does not know how s/he can find a way out of that critical situation. However, today băyadis used with a fixed form without any ending regardless of the person and number of the subject:

32) băyad be dănešgăh be-rav-im must to university NIN-go. NPS-PL

We must go to the university

Băyad takes negative marker, $n a$, regardless of the form of the lexical verb of the sentence:

33) na-băyad be-dav-i

NEG-must NIN-run.NPS-2SG

a) You don't have to run.

b) You must [not run]

c) It is improbable that you must run

Depending on the context, the above is open into three interpretations. First, it would be used in a context where there is no obligation for the addressee to run. This interpretation is conceivable by English translation a). In this interpretation the domain of negation belongs to the modality. Second, it would be used in a context 
where the addressee is obliged not to run. This interpretation is understood through translation b). In the latter interpretation, the domain of negation is with the proposition. Third, the sentence would be used in a context where, say, a group of people will be divided into two groups: a group that must run and a group that must not run. Using this sentence, the speaker informs the addressee that $\mathrm{s} / \mathrm{he}$ will be among those who are improbable to run. In this interpretation the domain of negation belongs to the modality.

34) na-băyad pul ră pas na-dah-ad

NEG-must money COMP back NEG-give. NPs-3SG

It is improbable that $\mathrm{s} / \mathrm{he}$ does not return the money

Sentence (34) would be used in a context where the speaker reasonably expects the person in question to return the money to a certain person. Here, not returning the money seems quite improbable because there is no reason for it.

It is quite common to use băyad with the negative form: of the lexical verb of the sentence. Compare (33) with (35), for instance:

35) băyad na-dav-i

must NEG-run. NPS-2sG

a) You must [not run]

b) Probably you will [not run]

As far as domain of negation is concerned, it refers to the proposition rather than the modality. However, the sentence is open into two interpretations. First, it would be used in a context where the addressee is obliged not to run. This is a typical example of deontic băyad in which the speaker speaks from a position of power and the addressee is obliged to follow the command (translation [a]). According to the second interpretation, it is reasonably probable that the addressee will not run. This is an epistemic use of the modal băyad.

The second modal auxiliary used in Modern Persian is šodan "become". It is most often used in spoken and informal language to express concepts such as ability, possibility, probability and permissibility in spoken Persian, depending on the context:

36) mi-še ostăd ră molăqăt kard

IMPF-can professor COMP meeting did. SHORTINFV

One can meet the professor

The above would be used in a context where it is possible (for the students) to meet the professor. It is an example of dynamic possibility because it is a sum of circumstances that provide the possibility of the event.

As a modal, šodan always appears in third person singular form regardless of the person and number the subject:

37) mi-še ketăb ră fardă bi-yăvar-i

IMPF-can book COMP tomorrow NIN-bring. NPS-2SG

You may bring the book tomorrow

The above would be used in a context where the subject has the authority to permit the addressee to return a certain book next day. Accordingly, it is an example of deontic possibility.

The third type of modality with šodan is epistemic though it is not as frequent as the other two types of modality. Consider the following, for instance:

38) mi-se alăn ali daredăre băš-e

IMPF-can now Ali in office NIN-be-2SG

Ali might be in office now

The above would be used in a context where somebody is looking for Ali but does not know where he is. The speaker, who thinks that Ali may be in his office at the speech time, addresses the addressee with the above sentence.

šodan can also be used in past tense form to express a counterfactual situation in the past, present or future:

39) mi-sod mosăbeqe ră dar tehrăn did

IMPF-could match COMP in Tehran watch. SHORTIN V

It was possible to watch the match in Tehran

The above is neutral to time, i.e., it can be used in present, past or future. Suppose one uses the sentence with a time adverbial such as hălă "now":

40) mi-šod hălă mosǎbeqe ră dar tehrăn did

IMPF-could now match COMP in Tehran watch. SHORTIN V 
It would be possible to watch the match in Tehran now

The above would be used in a context where the speaker would like to express a counterfactual situation in present time (speech time). This means that watching the match in Tehran is now impossible though it would have been possible to happen. It can also be used with a past time adverbial such as diruz "yesterday" to show a past time counterfactual situation. Sentence (40) can also be used with a future adverb to show a remote possibility in future time:

41) mi-šod fardă mosăbeqe ră dar tehrăn did

IMPF-could tomorrow match COMP in Tehran watch.

It would be possible to watch the match in Tehran

The above would be used in a context where the person already decided not to watch the match next day.

Modal šodancan also be used in a subjunctive form to show that an event is possible to happen. Consider the following, for instance:

43) šâyad be-šā $v$-ad xăne ră foruxt maybe NIN-can-3SG house COMP bought. SHORTINFV

One might be able to sell the house

In cases such as the above, šodancan be preceded by băyad with a similar use:

44) băyad be-ša v-ad moškel ră hall kard must NIN-can-3SG problem COMP solution did. SHORTIFV

One might be able to solve the problem

šodan takes negative marker regardless of any other verb of the sentence. Consider the following, for instance:

45) ne-mi-šav-ad raft

NEG-IMPF-can-3SGwent.SHORTINFV

One cannot go

46) mi-šav-ad na-raft

IMPF-can-3SGNEG-went.SHORTINFV

One can [not go]

47) ne-mi-sav-ad na-raft

NEG-IMPF-can-3SGNEG-went.SHORTINFV

One can't help going

Tavăn "can" is the last modal to be discussed. It is used only in impersonal constructions and has just two forms: subjunctive be-tavăn and imperfective mi-tavăn:

48) šăyad be-tavăn raft

maybe NIN-can went.SHORTINFV

Maybe one can go

49) mi-tavān raft

IMPF-can went. SHORTINFV

One can go

Betavăn, but not mi-tavăn, can be used with băyad:

50) băyad be-tavăn raft

must NIN-can went. SHORTINFV

One must be able to go

51) *băyad mi-tavăn raft

must IMPF-can went. SHORTINFV

As the other two modals, tavăntakes negative marker regardless of other verbs of the sentence:

52) ne-mi-tavăn raft

NEG-IMPF-can went. SHORTINFV

One cannot go

53) ne-mi-tavănna-raft

NEG-IMPF-can NEG-went. SHORTINFV

One can't help going

Tavăn can function epistemically, dynamically and deontically, depending on the context:

54) mi-tavăn entezăr piruzi dăst [epistemic] 
IMPF-can expectation victory had. SHORTINFV

One can expect victory

The above would be used in a context where, say, the speaker, regarding the overall condition of a football team, logically concludes that the team has a good chance of winning the game. Now, consider the following:

55) dar in šăhr mi-tavăn bă yek millyărd ye xăne xarid [dynamic]

In this city IMPF-can with one milliard one house bought. SHORTINFV

In this city, one can buy a house for one milliard Tumăn

The above would be used in a context where the price of a typical house is generally about one milliard Tumans in the city in question. This is a condition which is dictated by the circumstances of the market prices of houses.

Tavăn can also be used deontically. Consider the following, for instance:

56) dar in băq mi-tavăn miveh răyegăn xord [deontic]

in this garden IMPF-can fruit free ate. SHORTINFV

The above would be used in a context where the owner of the garden permits the visitors to eat different sorts of fruit charge free.

\section{Conclusion}

In this research, first we searched most authentic written texts related to Old Persian to see if this period of Persian contains any modal verbs. According to the data related to Old Persian it was proved that Old Persian lacked any modal verbs. In Middle Persian four verbs, namely, abāy- "must", šăy- "to deserve, to be able to" tav- "to be powerful" and saz- "to deserve, to be worthy" were used as modal verbs. All these four verbs had their roots in Old Persian where they had been used as main verbs. In fact, in an uncertain period of Middle Persian, four Old Persian lexical verbs obtained new capacities as modal verbs to mark events and situations whose actualization associated with concepts as necessity, possibility, permission, ability, probability and so on. In Modern Persian two of the above verbs, namely, băyad "must" and tavănestan "can” are still used as modals. The only new modal in Modern Persian is šodan "may". These three modal verbs of Modern Persian are used in expressing three kinds and three degrees of modality. By kinds of modality we mean deontic, epistemic and dynamic modalities. As far as degree of modality is concerned, we mean strong, medium and weak necessity or possibility of the actualization of the events of situations in question. According to our analysis, it is revealed that the rage and uses of modals in Middle Persian is wider than those in Modern Persian.

\section{References}

Abolghasemi, M. (2008). Historical Grammar of Persian. Tehran: SAMT Press.

Amuzgar, Z. A. T. (2007). Fifth Denkard: Phonology, Translation, Notes and Glossary, Phalavi Text (1st ed.). Tehran: Moeen Press.

Brandenstein, W., \& Mayrhofer, M. (1964). Handbuch des Altpersischen. Wiesbaden: Otto Harrassowitz.

Farahvashi, B. (1975). Kărnămak Ardashir Băbakăn (1st ed.) Tehran: Tehran University Press.

Givi, A., \& Anvari, H. (1991). Persian Grammar. Tehran: Fatemi Press.

Horn, P. (1893). Grundriss der Neupersischen Etymologie. Strasburg: Verlag von Karl J. Trübner.

Huddleston, R. (1984). English Grammar: An Outline. Cambridge: Cambridge University Press.

Huddleston, R., \& Pullum, G. K. (2002). The Cambridge Grammar of the English Language. Cambridge: Cambridge University Press.

Kellens, J. (1995). Liste du Verbe Avestique. Wiesbaden: Dr. Ludwig Reichert Verlag.

Kent, R. (1953). Old Persian: Grammar, Texts, Lexicon. New Haven: American Oriental Society.

Khanlari, N. P. (1987). Persian History. Tehran: Nashr-e Now.

Mackenzie, D. N. (1971). A Concise Pahlavi Dictionary. London: Oxford University Press.

Mansuri, Y., \& Hassanzadeh, J. (2008). An Etymological Study of Persian Verbs. Tehran: Farhangestan Press.

Meshkatodini, M. (2000). Persian Grammar Based on Transformational Theory. Mashad: Ferdowsi University Press.

Mirfaxraee, M. (2011). Phalavi Ravāyat (1st ed.). Tehran: Institute for Humanities and Cultural Studies. 
Oryan, S. (1992). Pahlavi Texts (1st ed.). Tehran: National Library of the Islamic Republic of Iran.

Palmer, F. (1990). Modality and the English Modals. London and New York: Longman.

Rahimian, J. (1995). Clause Types and Other Aspects of Clause Structure in Persian: A Study towards Comparison with English. Doctoral Dissertation, Brisbane: Queensland University.

Rahimian, J. (2012). Formal and Semantic Aspects of Modal Elements in Persian Sentences. Journal of Language and Linguistics, 13, 34-50.

Rahimian, J., \& Amuzadeh, M. (2013). Modality and Persian Modal Verbs. Linguistic Inquiry, 4, 1-24.

Rashed Mohassel, M. T. (2006). Vazīdagīha ī Zādasparam (2nd ed.). Tehran: Institute for Humanities and Cultural Studies.

Rostorgueva, V. S. (2000). Persian Grammar (trans. by Shădăn, 2nd ed.). Tehran: Association of Famous People and Cultural Works.

Shariat, M. J. (1985). Persian Grammar. Tehran: Asatir Press. 


\section{Phonemic Symbols}

\begin{tabular}{|c|c|c|c|}
\hline Symbols & Phonemic features & \multicolumn{2}{|c|}{ Examples } \\
\hline$Q$ & voiced, post-velar, stop & $q \hat{a} b$ & "frame" \\
\hline $\boldsymbol{x}$ & voiceless, post-velar, fricative & $x \breve{a k i}$ & “khaki” \\
\hline$I$ & unrounded, high, front & xâki & “khaki” \\
\hline $\boldsymbol{E}$ & unrounded, mid, front & del & “heart” \\
\hline$A$ & unrounded, low, front & $\operatorname{man}$ & “I” \\
\hline $\boldsymbol{U}$ & rounded, high, back & \multicolumn{2}{|c|}{ kuh "mountain" } \\
\hline $\boldsymbol{O}$ & rounded, mid, back & do & “two” \\
\hline$\breve{A}$ & rounded, low, back & bâd & "wind" \\
\hline
\end{tabular}

The other symbols used for the phonemic representation of Persian sentences are roughly the same as their English counterparts.

\section{Notational Conventions for Citing Persian Examples}

The Persian examples cited in this thesis have three representations: i) the phonemic representation of the Persian sentence; ii) an item-by-item gloss; iii) an English translation. Hyphens are used to indicate different components of a single Persian item and full stops show that the parts belong to the same Persian item. The grammatical and phonemic symbols used to represent Persian sentences are as follows:

$\begin{array}{ll}\text { SYMBOLS } & \text { GLOSS } \\ \text { CAN } & \text { modal TAVÂN } \\ \text { COMPlement marker } \\ \text { COMPRVE } & \text { comparativeadjective/adverb marker } \\ \text { IMPF } & \text { imperfective marker } \\ \text { INDEF } & \text { indefinite marker } \\ \text { INFV } & \text { infinitive marker } \\ \text { LINK } & \text { subordinator } e \\ \text { MAY } & \text { modal ŠOD-AN } \\ \text { MUST } & \text { modal BÂYAD } \\ \text { NEG } & \text { negative marker } \\ \text { NIN } & \text { non-indicative marker } \\ \text { NPS } & \text { non-past stem } \\ \text { PL } & \text { plural marker } \\ \text { PS } & \text { past stem marker } \\ \text { PN } & \text { person-number ending } \\ \text { PS } & \text { past stem } \\ \text { PTPCPL } & \text { participle } \\ \text { SG } & \text { singular }\end{array}$

